\title{
31 ORGANIZATIONAL LEARNING IN HEALTH CARE: Situating Free and Open Source Software
}

\author{
Gianluca Miscione \\ Margunn Aanestad \\ Department of Informatics \\ University of Oslo \\ Oslo, Norway
}

\section{ABSTRACT}

Free and open source software (FOSS) has been attracting the interest of organizations involved in the development and implementation of information and communication technologies (ICTs) in developing countries for years. ICTs for development initiatives often have public sector orientations, as governments' ICT policies are expected to shape and support socio-economical development. The usual mismatch between formal bureaucracies' functioning, the usual top-down software development schemes, and the actual trajectories of development initiatives (mostly run by international agencies) provides a promising empirical field. This paper intends to discuss the connection between FOSS and organizational learning in contexts where the usual assumptions about them cannot be taken for granted. It is argued that the relevance of open technologies as public goods is in allowing organizational learning in public administration. Such a focus on the organizational aspects would complement existing studies on the economical relevance of FOSS.

The argument is built by addressing FOSS-related emphatic expectations for emancipation in the "knowledge society" on one side (Government of Kerala 2002), and implementation and use, on the other. Then, a meso-level between global trends and local specificities is identified as crucial in situating FOSS for development potentialities. Empirically, this level is between the two usual poles in information systems studies: decision makers (public administrators and software developers, both oriented by a top-

Please use the following format when citing this chapter:

Miscione, G., and Aanestad, M., 2008, in IFIP International Federation for Information Processing, Volume 267, Information Technology in the Service Economy: Challenges and Possibilities for the $21^{\text {st }}$ Century, eds. Barrett, M., Davidson, E., Middleton, C., and DeGross, J. (Boston: Springer), pp. 371-373. 
down approach to systems design) and the ground of implementation (usually sensitive to a variety of contexts). As it is unusual in developing contexts to have spontaneous voluntary participation, the software development process needs to be designed and carried out in a way that allows local organizations to "indigenize" FOSS. ${ }^{1}$ Its fluidity allows inscribing a variety of context-bound socio-technical arrangements (De Laet and Mol 2000), and also can cause avoidance of path-dependencies and vendor lock-ins (Weerawarana and Weeratunge 2004).

The case of a health information system being implemented in Kerala, as part of an international initiative, is presented. We describe, on one side, the principles and views supporting the network and local politics and, on the other side, aspects of the implementation dynamic, which is underestimated in the common approach to ICT for development (Avgerou 2007).

The project presented in the paper has significant links both at the global level (participating in a broad and heterogeneous network of trend-setting organizations like universities and research centers, international donors, ministries of different countries) and local levels (where systems are piloted and implemented, capacity building is carried out, requirements for further developments are collected). Empirical exploration showed that the (formal and informal) institutional constraints, which FOSS implies and relies on, are fragmented or absent, whereas others can be relevant. Nevertheless, FOSS narrative proves to be present and effective both in negotiations between stakeholders, and in facilitating local participation to information system development. ${ }^{2}$

The meso-level position of this initiative shows the distance between the two ends, descriptively. Prescriptively, it suggests how possible bridges can allow interorganizational relations across a variety of actors rarely involved in the same FOSS initiative. The interactions around local technical skills improvement and the increased ability for organizations to formulate, express, negotiate, and inscribe their needs in technology is proposed as a chance for organizational learning. In contexts of multiple accountabilities (Suchman 2002), we claim that the relevance of FOSS emerges from negotiating alliances, and does not inhere in FOSS itself. FOSS facilitates learning as far as its openness is allowed by software development processes, and enacted by brokering activities to relate dispersed practices (Gherardi and Nicolini 2002).

\section{References}

Avgerou C. 2007. "Information Systems in Developing Countries: A Critical Research Review," Working Paper Series, Innovation Group, London School of Economics and Political Sciences, October.

Camara G., and Fonseca F. 1997. "Information Policies and Open Source Software in Developing Countries," Journal of the American Society for Information Science and Technology (58:1), pp. 121-132.

${ }^{1}$ Camara and Fonseca (2007) relate modalities of participation to code writing and software modularity.

${ }^{2}$ Myths and narratives are discussed by Czarniawska (1997) in neoinstitutional terms. The legitimizing role of myth is clearly presented by Noir and Walsham (2007), also through a case from Kerala. 
Czarniawska B. 1997. Narrating the Organization: Dramas of Institutional Identity, Chicago: University of Chicago Press, Chicago.

De Laet, M., and Mol, A. 2000. "The Zimbabwe Bush Pump: Mechanics of a Fluid Technology," Social Studies of Science (30), pp. 225-263.

Gherardi, S., and Nicolini, D. 2002. "Learning in a Constellation of Interconnected Practices: Canon or Dissonance," Journal of Management Studies (39:4), pp. 419-436.

Government of Kerala. 2007. "Information Technology Policy: Towards an Inclusive Knowledge Society" (http://www.keralaitmission.org/web/main/ITPolicy-2007.pdf)

Noir, C., and Walsham G. 2007. "The Great Legitimizer: ICT as Myth and Ceremony in the Indian Healthcare Sector," Information, Technology \& People (20:4), pp. 313-333.

Suchman, L. 2002. "Located Accountabilities in Technology Production," Scandinavian Journal of Information Systems (14:2), pp. 91-105.

Weerawarana, S., and Weeratunge, J. 2004. Open Source in Developing Countries, Swedish International Development Cooperation Agency, January (http://www.eldis.org/fulltext/ opensource.pdf).

\section{About the Authors}

Gianluca Miscione received his Ph.D. in Information Systems and Organization from the Sociology Department of the Universityof Trento (Italy) with a dissertation focused on the interplay between information and communication technologies and health care change in "developing" contexts. At the University of Oslo, his research focuses on information infrastructures and organizational studies. Gianluca can be reached at gianluca.miscione@gmail.com.

Margunn Aanestad is a researcher at the Department of Informatics, University of Oslo. She worked in the health care and telecommunications industries before her doctoral study of surgical medicine. Margunn's research interests are broadly related to large-scale information infrastructures, specifically in health care. She can be reached at margunn@ifi.uio.no. 